\title{
RASIONALISASI PERSPEKTIF FILM LAYAR LEBAR BERADAPTASI KARYA SASTRA
}

\author{
Pheni Cahya Kartika \\ Universitas Muhammadiyah Surabaya \\ Email: phenicahya.sulistiyo@gmail.com
}

\begin{abstract}
Abstrak
Film salah satu media visual super penting yang berkembang di Indonesia. Film hanya akan bermakna jika bertemu dengan penontonnya. Kesediaan menyaksikan film Indonesia menjadi hal yang sangat penting. Menurut survei sebagian besar penikmat film layar lebar menyukai film yang beradaptasi dari karya sastra seperti novel. Penelitian ini merupakan jenis penelitian kualitatif dalam bidang kajian sastra dan berkonsentrasi pada nilai psikologi sosial edukatif. Berdasarkan analisa dapat disimpulkan bahwa pecinta film lebih tertarik pada film yang mengadopsi novel karena alur cerita yang seringkali membuat kesan baik terutama pada kepribadian mereka. Karya sastra seperti novel mampu diajarkan dan dinikmati pula dengan hadirnya film yang syarat akan nilai edukatif. Dibandingkan dengan film yang tidak mengadopsi karya sastra, pecinta karya sastra kadang tidak lebih tertarik pada film dengan beberapa alasan yang dinilai cukup rasional. Perbedaan jalan cerita dan imajinasi yang syarat komersial dinilai mengurangi ruh dari sebuah judul karya sastra.
\end{abstract}

Kata Kunci: film, karya sastra, novel, perspektif

\begin{abstract}
Film as one of super important visual media is currently growing in Indonesia. Films will only be meaningful if it meets with the audience. Indonesia's willingness to watch the movie becomes very important. According to the survey the majority of wide screen film lovers, films adapted from literary works such as novels. This research is qualitative research in the field of literary studies and concentrate on the educational value of social psychology. Based on the analysis, it can be concluded that moviegoers are more interested in the film because of adopting novel storyline that often make a good impression, especially on their personality. Literary works such as novels able to be taught and enjoyed also by the presence of the film that this requirement will be educational
\end{abstract}


value. Compared with the films that did not adopt a literary work, lovers of literature are sometimes not more interested in movies with some reason considered quite rational. Differences in the way the story and imagination commercial terms was seen as reducing the spirit of a literary work's title.

Keywords: film, literary works, novel, perspective

\section{PENDAHULUAN}

Sebuah karya tentunya tidak terlepas dari siapa penciptanya, karenanya bersifat mutlak. Bahkan semua itu dapat ditemui pada sebuah film dan karya sastra, misalkan pantun, puisi, novel, drama bahkan roman. Nampaknya novel lebih banyak memberikan sumbangsih ide para pencipta film layar lebar. Respon masyarakat dalam mengapresiasi hasil cipta tentunya beragam, karena masyarakat memang serasa ditakdirkan untuk menikmati apapun yang disuguhkan dimata mereka. Film merupakan sebuah media yang dapat menuangkan realitas kehidupan ke dalam sebuah layar lebar (joseph, 2011).

Pengertian film secara harfiah yakni sinema, dijelaskan yakni cinemathographic yang berasal dari kata cinema dan tho/ "phytos" yakni cahaya serta graphic adalah tulisan/gambar/ citra, bisa dikatakan film tersebut berarti melukiskan suatu gerak dengan cahaya.Film salah satu media visual super penting yang berkembang dilndonesia, bahkan penyuka film bukan hanya mampu berestetis saja melainkan beberapa komponen masyarakat tertentu sampai terinspirasi hidupnya sebagai efek pribadi dari film yang digemarinya. Film hanya akan bermakna jika bertemu dengan penontonnya, Oleh karena itu kesediaan penonton menyaksikan film Indonesia menjadi hal yang sangat penting. Perkembangan film di Indonesia mengalami kemajuan yang cukup pesat, jika diamati dari jumlah, 
penonton sinema nasional merangkak naik. Bila pada tahun 2000 pangsa pasar film nasional hanya 7,46 persen, maka pada 2008 mencapai 50 persen (Servia 2007, dikutip dalam Barker 2011). Kemudian pada tahun 2008-2009 dapat dikatakan sebagai puncak perolehan penonton karena mencapai 30 juta.

Dengan jumlah produksi film yang tak terlalu berbeda, ketertarikan penonton memilih film nasional terus menurun sejak 2010 hingga 2013 (Kristanto dan Pasaribu, 2011). Siapakah penonton di tahun-tahun puncak dan mengapa mereka tidak kembali menonton film nasional? Tentunya ini seperti pertanyaan yang harus pula dipikirkan oleh pembuat film. persaingan yang syarat dengan komersil sering dijadikan alasan pencipta film untuk terus berkarya, akan timbul suatu pertanyaan lain, apakah benar bahwa fenomena selama ini bahwa film dan karya sastra merupakan indutri seni yang syarat komersial tinggi, dan apakah benar bahwa hasil pemvisualan naskah tulis lebih menyakinkan penikmat untuk menginspirasi mereka, Tentunya jawaban itu bergantung pada tingkat kepedulian dalam mengapresiasi suatu karya baik film maupun sastra. Banyak film yang dengan sengaja disuguhkan pada masyarakat, sehingga memberikan kesempatan pada masyarakat untuk menikmati, mengapresiasi, serta merespon sebagai hasil dari karya sang pembuat film, tampaknya respon menikmat film juga memiliki klasifikasi tersendiri dalam memilih, baik film yang berlatarbelakang percintaan, sosial masyarakat, religius islami, komedi, horor, bahkan politik, membuat giat para pemerhati dan pembuat film terus berkarya.

Mari kita perhatikan catatan film-film terlaris dalam sejak 2008-2012 berturut-turut: Laskar Pelangi (Riri Riza), Ketika Cinta Bertasbih (Chaerul Umam), Sang Pencerah (Hanung Bramantyo), Surat Kecil untuk 144 | ISSN: 22477-5150 http://journal.unesa.ac.id/index.php/jpi 
Pheni Cahya Kartika, Rasionalisasi Perspektif Film...(hal. 142-158)

Tuhan (Harris Nizam), Habibie \& Ainun (Faozan Rizal), Cinta Brontosaurus (Fajar Nugros). Jika dicermati ada beberapa kecenderungan film terlaris tersebut. Beberapa di antaranya film berbasis novel laris seperti Laskar Pelangi, Ketika Cinta Bertasbih, Surat Kecil untuk Tuhan, Cinta Brontosaurus. Sedangkan kedua film lainnya yaitu Sang Pencerah dan Habibie \& Ainun adalah biografi tokoh terkenal yaitu KH. Ahmad Dahlan (pendiri ormas Islam terbesar Muhammadiyah) dan BJ Habibie (mantan Presiden RI). Popularitas film-film terlaris Indonesia bersandar pada budaya populer lain yaitu novel dan biografi tokoh.

Dapat dikatakan penonton datang ke bioskop bukan karena film itu sendiri tetapi buzz berita yang melingkupi judul film tersebut seperti popularitas novel dan tokoh. Maka dapat disimpulkan pecinta film Indonesia sebetulnya belum terbentuk benar. Selera mereka masih belum dapat diidentifikasi dengan tegas. menurut survei sebagian besar penikmat film layar lebar menyukai film yang beradaptasi dari karya sastra seperti novel. Hal tersebut juga menjadi alasan para pengarang karya sastra juga berantusias untuk terus berkarya, dalam penelitian Dyna ( 2014) yang mengkaji respon penonton film indonesia di bioskop, mendapati beberapa pernyataan setelah melakukan tiga kali focus group discussion yang melibatkan 20 informan.

Berdasarkan hasil analisis kualitatif, ditemukan lima faktor utama yang terdiri dari 18 faktor pendukung yaitu komunikasi pemasaran (iklan dan publisitas), sumber informasi netral (ulasan film dan komunikasi dari mulut ke mulut), karakteristik film (genre, sutradara, remake, asal negara, pemain, karya saduran, rumah produksi), konten (cerita,objectionable content, teknologi), kemudahan (waktu pemutaran dan judul). Dan dari 
pengkajiaanyapun ditemukan bahwa faktor yang menonjol secara statistik adalah cerita film. Kehadiran dunia maya membuat penonton dengan mudah menemukan sinopsis sebelum memutuskan menonton film di bioskop. Maka pilihan produser film mengangkat cerita novel populer ke layar kaca menjadi strategi yang jitu.

Film berbasis novel tersebut kemudian laris di bioskop karena penonton tersebut sejatinya adalah pembaca novel. Sudah sepatutnya kita mempertimbangkan adanya karya sastra yang turut serta memajukan film di Indonesia, namun persoalannya tentu bukan semata ketersediaan dan kelimpahan karya-karya tersebut, tetapi pada soal adaptasi karya-karya ini ke dalam film. Soalnya yang pertama, apakah karya-karya sastra itu perlu dan layak, terutama dari segi cerita (dan juga dari segi komersial), untuk difilmkan. Yang kedua, pada kemampuan untuk mengadaptasinya. Sastra dan film memiliki bahasa dan logika penceritaan yang berbeda. Karena berbedanya bahasa yang diekspresikannya, pengadaptasian sebuah karya sastra yang berbasis pada bahasa tulis ke bahasa film yang berbasis visual, tentu butuh keterampilan dan kemampuan yang khas. Karya-karya sastra dalam bentuk buku baru merupakan bahan mentah atau baru sebagai bibit. Keduanya perlu diolah atau dipupuk dan disiram. Tahap awalnya adalah penulisan skenario (dari tiga tahap pembuatan film sebelum penyutradaraan dan penyuntingan).

Naskah skenario menentukan baik tidaknya sebuah film. Karya sastra yang baik tetapi skenarionya tidak ditulis dengan bagus akan menjadi film yang juga tidak baik atau apik. Sebaliknya suatu karya sastra yang biasa saja kalau diskenario oleh ahlinya dengan tepat maka akan menghasilkan film yang baik, tentunya syarat akan naik daun di negara kita. Selanjutnya tinggal bagaimana para penikmat film maupun pembaca sastra khususnya 146 | ISSN: 22477-5150 http://journal.unesa.ac.id/index.php/jpi 
novel mulai memikirkan tingkat kerelevanan pikirannya terhadap analisis diatas, peneliti menfokuskan pada permasalahan yakni analisis rasionalisasi perspektif penikmat film beradaptasi karya sastra dan perspektif pembuat film beradaptasi karya sastra, agar diperoleh gambaran apakah benar adanya rasionalisasi antara penikmat film dengan pembuat film, sehingga terjadi sinergitas baik untuk keberlangsungan film maupun karya sastra pada era masa depan.

\section{METODE PENELITIAN}

Penelitian ini merupakan jenis penelitian kualitatif. Penelitian ini termasuk dalam bidang kajian sastra, pada konsentrasi kajian nilai psikologi sosial edukatif. Penelitian ini termasuk kepada jenis content analisys atau analisis isi. Content analisys menekankan kajian kepada isi dari objek yang diteliti. Sumber data penelitian ini adalah nilai psikologi sosial edukatif pada sebuah karya sastra yang diadaptasi kedalam sebuah film yakni novel. Sesuai dengan jenis sumber data di atas, pengumpulan data dalam penelitian ini dilakukan dengan menggunakan metode perpustakaan

Teknik analisis data yang digunakan adalah teknik analisis deskriptif kualitatif. Peneliti mendeskripsikan wujud responsif dan kajian pustaka berdasarkan data-data yang telah terkumpul, baik berupa analisa pustaka terdapat dalam subjek penelitian. Langkah-langkah yang digunakan untuk menganalisis data dalam penelitian ini adalah sebagai berikut. (1) Mengidentifikasi jenis film yang beradaptasi karya sastra (tabel 1) (2) selanjutnya pengidentifikasian difokuskan pada 3 unsur rasionalisasi perspektif yang deskripsian yakni pencipta karya sastra, pembuat film 
beradaptasi karya sastra dan penikmat film dan karya satra (3) memberikan analisis terhadap unsur-unsur tersebut, dan (4) memberikan interpretasi.

\section{PEMBAHASAN}

Film yang beradaptasi karya sastra

Peneliti mencoba menganalisis film layar lebar yang mengadopsi novel antara lain:

10 Film Indonesia peringkat teratas dalam perolehan jumlah penonton pada tahun 2010 berdasarkan tahun edar film

\begin{tabular}{llr}
$\#$ & Judul & Penonton \\
\hline 1 & Sang Pencerah & $* 1.206 .000$ \\
\hline 2 & Dalam Mihrab Cinta & 623.105 \\
\hline 3 & $18+:$ True Love Never Dies & 518.527 \\
\hline 4 & Pocong Rumah Angker & 503.450 \\
\hline 5 & Kabayan Jadi Milyuner & 477.076 \\
\hline 6 & Menculik Miyabi & 447.453 \\
\hline 7 & Tiran (Mati di Ranjang) & 418.347 \\
\hline 8 & Darah Garuda (Merah Putih II) & 407.426 \\
\hline 9 & Akibat Pergaulan Bebas & 402.969 \\
\hline 10 & Satu Jam Saja & 401.649
\end{tabular}


Pheni Cahya Kartika, Rasionalisasi Perspektif Film...(hal. 142-158)

10 Film Indonesia peringkat teratatahun 2011 dalam perolehan jumlah penonton pada tahun 2011 berdasarkan tahun edar film

\# Judul

Penonton

1 Surat Kecil Untuk Tuhan

748.842

$2 \quad$ Arwah Goyang Karawang

727.540

3 Hafalan Shalat Delisa

668.731

$4 \quad$ Poconggg Juga Pocong

622.689

$5 \quad$ Get Married 3

601.786

6 Tanda Tanya

552.612

7 Purple Love

520.786

8

Di Bawah Lindungan Ka'bah

520.267

$9 \quad$ Tendangan dari Langit

491.077

10 Catatan Harian Si Boy

$* 450.000$

10 Film Indonesia peringkat teratas dalam perolehan jumlah penonton pada tahun 2012 berdasarkan tahun edar film

\# Judul

Penonton

1

Habibie \& Ainun

4.529 .633

2

$5 \mathrm{~cm}$

2.392.210

3

The Raid

1.844 .817 


\begin{tabular}{llr}
$\#$ & Judul & Penonton \\
\hline 4 & Negeri 5 Menara & 772.397 \\
\hline 5 & Perahu Kertas & 596.231 \\
\hline 6 & Soegija & 459.465 \\
\hline 7 & Nenek Gayung & 434.732 \\
\hline 8 & Rumah Kentang & 413.102 \\
\hline 9 & Perahu Kertas 2 & 393.653 \\
\hline 10 & Rumah Bekas Kuburan & 284.733
\end{tabular}

10 Film Indonesia peringkat teratas dalam perolehan jumlah penonton pada tahun 2013 berdasarkan tahun edar film

\# Judul

Penonton

1 Tenggelamnya Kapal Van Der Wijck

1.724 .110

299 Cahaya di Langit Eropa

1.189.709

3 Soekarno: Indonesia Merdeka

960.071

$4 \quad$ Cinta Brontosaurus

892.915

5 Coboy Junior The Movie

683.604

6 Taman Lawang

526.761

7 Manusia Setengah Salmon

442.631

$8 \quad$ Laskar Pelangi 2: Edensor

390.810

150 | ISSN: 22477-5150 http://journal.unesa.ac.id/index.php/jpi 
Pheni Cahya Kartika, Rasionalisasi Perspektif Film...(hal. 142-158)

\# Judul

Penonton

$9 \quad 308$

10 Get M4rried

315.390

Film Indonesia peringkat teratas dalam perolehan jumlah penonton pada tahun 2014 berdasarkan tahun edar film

\# Judul

Penonton

1 Comic 8

1.624 .067

$2 \quad$ The Raid 2: Berandal

1.434 .272

$3 \quad$ Merry Riana: Mimpi Sejuta Dolar

715.671

$4 \quad$ Hijrah Cinta

711.205

$5 \quad$ Marmut Merah Jambu

640.682

699 Cahaya di Langit Eropa Part 2

587.042

$7 \quad$ Assalamualaikum Beijing

560.465

8 Supernova: Ksatria, Putri, \& Bintang Jatuh

501.258

9 Bajaj Bajuri The Movie

460.779

10 Haji Backpacker

375.799

10 Film Indonesia peringkat teratas dalam perolehan jumlah penonton pada tahun 2015 berdasarkan tahun edar film

\# Judul

Penonton 
\# Judul

Penonton

1 Surga yang Tak Dirindukan

1.523.617

$2 \quad$ Single

1.351 .324

3 Comic 8: Casino Kings part 1

1.211 .820

$4 \quad$ Bulan Terbelah di Langit Amerika

917.865

5 Magic Hour

859.705

$6 \quad$ Ngenest

785.786

$7 \quad$ Di Balik 98

684.727

83 Dara

666.183

$9 \quad$ Negeri Van Oranje

490.788

10 Air Mata Surga

425.179

Tabel rekapitulasi karya sastra (novel) yang diadaptasi kedalam film tahun 2010-2015

Berdasarkan tabel tersebut, bahwa kebanyakan film yang mendapatkan respon baik dengan perolehan jumlah pengunjung bioskop yakni pada film yang mengadopsi novel, peneliti mencoba pula mengkajinya pada tabel berikut

\begin{tabular}{|l|l|l|l|l|}
\hline No & \multicolumn{1}{|c|}{ Judul Novel } & \multicolumn{1}{|c|}{ Judul Film } & Tahun & Keterangan \\
\hline 1 & Air mata surga & Air mata surga & 2015 & Percintaan \\
\hline 2 & $\begin{array}{l}\text { Bulan terbelah } \\
\text { dilangit amerika }\end{array}$ & $\begin{array}{l}\text { Bulan terbelah } \\
\text { dilangit amerika }\end{array}$ & 2015 & \\
\hline 3 & Surga yang tak & Surga yang tak & 2015 & \\
\hline
\end{tabular}


Pheni Cahya Kartika, Rasionalisasi Perspektif Film...(hal. 142-158)

\begin{tabular}{|c|c|c|c|c|}
\hline & dirindukan & dirindukan & & \\
\hline 4 & $\begin{array}{l}99 \text { Cahaya di } \\
\underline{2} \\
\underline{2}\end{array}$ & $\begin{array}{l}\frac{99 \text { Cahaya di }}{\text { Langit Eropa Part }} \\
\underline{2}\end{array}$ & 2014 & \\
\hline 5 & $\begin{array}{l}\text { Assalamualaikum } \\
\text { Beijing }\end{array}$ & $\begin{array}{l}\text { Assalamualaikum } \\
\text { Beijing }\end{array}$ & 2014 & \\
\hline 6 & $\begin{array}{l}\text { Supernova: } \\
\text { Ksatria, Putri, \& } \\
\text { Bintang Jatuh }\end{array}$ & $\begin{array}{l}\text { Supernova: } \\
\text { Ksatria, Putri, \& } \\
\text { Bintang Jatuh }\end{array}$ & 2014 & \\
\hline 7 & Edensor & Laskar pelangi 2 & 2013 & $\begin{array}{l}\text { Sosial } \\
\text { edukatif }\end{array}$ \\
\hline 8 & $\begin{array}{l}\text { Tenggelamnya } \\
\text { kapal van der } \\
\text { wijck }\end{array}$ & $\begin{array}{l}\text { Tenggelamnya } \\
\text { kapal van der } \\
\text { wijck }\end{array}$ & 2013 & $\begin{array}{l}\text { Sejarah dan } \\
\text { percintaan }\end{array}$ \\
\hline 9 & $\begin{array}{l}99 \text { Cahaya } \\
\text { dilangit eropa }\end{array}$ & $\begin{array}{l}99 \text { Cahaya } \\
\text { dilangit eropa }\end{array}$ & 2013 & Religius \\
\hline 10 & $\begin{array}{l}\text { Manusia } \\
\text { setengah salmon }\end{array}$ & $\begin{array}{l}\text { Manusia } \\
\text { setengah salmon }\end{array}$ & 2013 & $\begin{array}{l}\text { Komedi } \\
\text { Percintaan }\end{array}$ \\
\hline 11 & Air mata bunda & Air mata bunda & 2013 & Edukatif \\
\hline 12 & Perahu kertas & Cinta Brotosaurus & 2012 & \\
\hline 13 & Negeri 5 menara & & 2012 & \\
\hline 14 & $3 \mathrm{~cm}$ & & 2012 & \\
\hline 15 & $\begin{array}{l}\text { Dibawah } \\
\text { lindungan kabah }\end{array}$ & & 2012 & \\
\hline 16 & Sang penari & & 2011 & \\
\hline
\end{tabular}




\begin{tabular}{|l|l|l|l|l|}
\hline 17 & $\begin{array}{l}\text { Dibawah } \\
\text { lindungan kabah }\end{array}$ & 2011 & \\
\hline 18 & $\begin{array}{l}\text { Ketika Cinta } \\
\text { Bertasbih }\end{array}$ & & 2011 & \\
\hline 19 & $\begin{array}{l}\text { Dalam mihrab } \\
\text { cinta }\end{array}$ & & 2010 & \\
\hline
\end{tabular}

Kurang lebih 19 film yang beradopsi novel yang mampu diangkat pada film layar lebar, dengan jumlah penikmat film yang cukup banyak.

\section{Rasionalisasi Perspektif}

Pendeskripsian untuk kajian rasionalisasi perspektif yakni pengkrucutan pada 2 (dua) hal yakni pembuat film beradaptasi karya sastra, dan penikmat film dan karya satra, maka akan terlebih dulu kita menjabarkan maksud dari rasionalisasi, Menurut KBBI yakni pikiran dan pertimbangan yang logis; menurut pikiran yang sehat; cocok dengan akal; Pemikiran rasional adalah cara berpikir menggunakan penalaran berdasarkan data yang tersedia untuk mencari kebenaran faktual, keuntungan dan tingkat kepentingan. Manusia harus menggunakan pemikiran rasional jika ingin maju dan mengejar ilmu pengetahuan.

Berpikir rasional selain itu menjadi sangat diperlukan saat bekerja untuk kepentingan publik, berkaca dari definisi tersebut jika dikaitkan tentang bagaimana kita merasionalkan keberadaan film indonesia yang mengadopsi karya sastra maka harus yang syarat dengan kepentingan masyarakat tentunya diimbangi dengan pengetahuan dan nilai, perlu adanya alasan objektif yang bisa ditunjukkan kepada khayalak umum dengan bukti bukti dan referensi fakta yang logis dan relevan. Setiap orang 154 | ISSN: 22477-5150 http://journal.unesa.ac.id/index.php/jpi 
Pheni Cahya Kartika, Rasionalisasi Perspektif Film...(hal. 142-158)

akan selalu berupaya menjalankan pemikirannya dengan rasional namun tidak semua,ada beberapa hal yang bisa kita lakukan untuk menigkatkan kemampuan berpikir rasional antara lain mampu menganalisa, memperdalam pengetahuan, menerima informasi yang objektif, kritis, dan membaca tentunya.

\section{Analisis Perspektif}

Definisi perspektif adalah konteks sistem dan persepsi visual adalah cara bagaimana objek terlihat pada mata manusia berdasarkan sifat spasial, atau dimensinya dan posisi mata relatif pada objek. Pengertian lain menyebutkan bahwa perspektif adalah asumsi asumsi dasar yang paling banyak sumbangannya pada pendekatan psikologi sosial. Ahli psikologi membedakannya kedalam 2 hal yakni perspektif kognitif yakni perilaku sosial seseorang dengan cara memusatkan bagaimana sesorang tersebut menyusun mental (pikiran, perasaan) dan memproses informasi baru dari lingkungannya, sedangkan perspektif perilaku menyatakan bahwa perilaku sosial seseorang yang paling baik dijelaskan melalui perilaku secara langsung dapat diamati dan penyebab perilaku seseorang tersebut berubah. Namun ada dua perspektif yang dimunculkan oleh ahli psikologi sosial yakni perspektif struktural adalah memusatkan perhatian pada proses sosialisasi yakni proses dimana perilaku seseorang dibentuk oleh peran yang beraneka ragam, dan selalu berubah, yang dirancang oleh masyarakat sekitar. Sedangkan perspektif interaksionis memusatkan perhatiaanya pada proses interaksi yang mempengaruhi perilaku sosial seseorang. Perbedaan utama diantara kedua perspektif tersebut bisa disimpulkan pada pihak mana yang berpengaruh paling besar terhadap 
pembentukan perilaku. Kaum strukturalis cenderung meletakkan struktur sosial "makro" sebagai perilaku sosial seseorang.

Responsif yang muncul pada perspektif seseorang dianalisis sebagai berikut

\begin{tabular}{|c|c|c|c|c|}
\hline \multicolumn{5}{|c|}{ Perspektif } \\
\hline & perilaku & kognitif & interaksional & struktural \\
\hline $\begin{array}{l}\text { Pencipta karya } \\
\text { sastra }\end{array}$ & & & Muncul & \\
\hline $\begin{array}{l}\text { Penikmat film dan } \\
\text { karya sastra }\end{array}$ & muncul & Muncul & Muncul & muncul \\
\hline Pembuat film & & muncul & muncul & muncul \\
\hline
\end{tabular}

Keterangan berdasarkan tabel diatas, maka persepektif interaksional lebih mendominasi dan mengarah pada 3 (tiga) komponen tersebut, sedangkan dari segi subjek penikmat film dan karya sastra lebih memberikan pengaruh besar dalam merasionalkan perspektifnya, baik secara perilaku, kognitif, interaksional maupun struktural. Meski pembuat film dan pencipta karya sastra kadang mampu menahkodai dan memberikan efek besar pada pemikiran para penikmat, namun keberadaannya sebagai konsumen mampu memunculkan perspektif beragam yang lebih rasional. Maka berbicara tentang penikmat film dan karya sastra. Dyna, 2013 mengelompokkan menjadi 2 pecinta karya sastra dan pecinta film, dimana pecinta karya sastra kadang tidak segitu meminati suatu film dengan beberapa alasan yang dinilai cukup rasional, perbedaan jalan cerita dan mengfiksiian yang syarat komersial dinilai mengurangi roh dari sebuah judul karya sastra,beda dengan kelompok kedua adalah pencinta film (film-lovers). Penonton jenis ini menonton film 156 | ISSN: 22477-5150 http://journal.unesa.ac.id/index.php/jpi 
bioskop untuk mendapatkan pengalaman baru dan nilai moral kehidupan. Mereka seringkali merenungkan isi film, mencatat kata-kata yang bermakna, dan mengkaitkan dengan hidup sehari-harinya. Responden yang berada dalam kategori ini sejumlah 162 (35,68\%). Perbedaan penting antara pecinta karya sastra dan pecinta film (film-lovers) berkaitan dengan faktor yang mereka perhatikan dalam mengkritisi film. Kluster filmlovers memberikan perhatian yang lebih besar pada sinopsis koran, majalah, ulasan film di website, koran dan majalah, sutradara, adaptasi serial televisi, rumah produksi. Mereka cenderung memilih waktu pemutaran di malam hari libur daripada waktu-waktu lain. Perilaku kedua segmen ini setelah menonton film juga cukup berbeda. Sedangkan pecinta film (film-lovers), jika merasa puas dengan film yang ditontonnya akan bersedia menjadi komunikator film dengan cara menuliskan pendapat mengenai film di blog pribadi, situs jejaring sosial, forum perbincangan di internet dan komunikasi interpersonal.

\section{SIMPULAN}

Analisis sesuai dengan kajian pustaka mengenai rasionalisasi perspektif film layar lebar beradaptasi karya sastra yang telah dipaparkan diatas dapat memberikan kesimpulan

a. Pecinta film lebih tertarik pada film yang mengadopsi novel karena alur cerita yang seringkali membuat kesan baik terutama pada kepribadian mereka, amanat yang jelas tentunya berpengaruh pula pada perilaku para pecinta film. 
b. Karya sastra seperti novel mampu diajarkan dan dinikmati pula dengan hadirnya film yang syarat akan nilai edukatif, dibandingkan yang tidak mengadopsi karya sastra.

c. pecinta karya sastra kadang tidak segitu tertarik pada film dengan beberapa alasan yang dinilai cukup rasional, perbedaan jalan cerita dan mengfiksiian yang syarat komersial dinilai mengurangi roh dari sebuah judul karya sastra.

\section{DAFTAR RUJUKAN}

Eric Sasono. 2005 diterbitkan kembali: http://www.bbc.com/indonesia/majalah/2015/10/151005 majalah f ilm indonesia

2016. Diterbitkan kembali:

www.gelombangotak.com

2016, diterbitkan kembali

http://filmindonesia.or.id/movie/viewer/2014\#.VzdVJ5FcSkp

Herlina, Dyna. 2013. Cinema Audience Segmentation Analysis: A Mix Method Approach. Penelitian Fakultas Ekonomi, Universitas Negeri Yogyakarta, tidak diterbitkan

Herlina, Dyna. 2014 diterbitkan kembali:

http://filmindonesia.or.id/article/siapa-penonton-filmindonesia\#.VzbnuPI97IU

Kristanto, JB., Pasaribu, Jonathan, Adrian. 2011. Catatan 2011: Menonton Penonton

Kamus Besar Bahasa Indonesia. ---------------. Diterbitkan kembali: http://kbbi.web.id/ 